\title{
The development of the serum protein pattern in Africans
}

\author{
J. C. EDOZIEN
}

From the Department of Chemical Pathology, University College, Ibadan, Nigeria

SYNOPSIS The serum protein of African and European mothers, African and European umbilical $\vec{A}$ cord blood, and African children up to $6 \frac{1}{2}$ years of age have been investigated. African umbilical $\%$ cord blood contains significantly higher concentrations of $\gamma$ globulin than European umbilical cord blood. Significant differences were not found in the other protein fractions. The level of $\gamma$ globulin 0

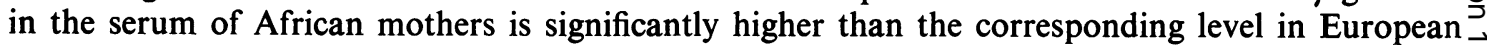
mothers. Significant differences were not observed in the other protein fractions. The changes in $Z$ serum proteins in pregnancy in African women follow the pattern described in European women. Close correlation was demonstrated between the level of maternal and cord blood $\gamma$ globulin. The $\frac{\Phi}{3}$ significance of this finding has been discussed.

It is concluded that hereditary factors cannot be excluded until further iniormation on the level $\overrightarrow{\mathscr{Q}}$ of $\gamma$ globulin of Europeans and other races subjected to the conditions of life of the average African is available.

Although it is generally accepted that repeated contact with the malaria parasite and possibly other pathogenic organisms is the immediate stimulus for healthy Africans to maintain a higher serum gamma globulin concentration than Europeans (Holmes, Stanier, and Thompson, 1955; McGregor, Gilles, Walters, Davies, and Pearson, 1956; Edozien, Boyo, and Morley, 1960), recent comparative studies of the serum proteins in different population groups have also suggested that the difference in serum $\gamma$ globulin concentration between ethnic groups may have a genetic basis (Rawnsley, Yonan, and Reinhold, 1956; Vera and Roche, 1956; Edozien, 1957, 1958; Bakker, Bliek, and Luyken, 1957; Comens, 1957; Curnow, 1957; Keltz and Comstock, 1959). The immunological and hereditary factors are not mutually exclusive, because it is possible that in certain environments, the process of natural selection may operate in favour of individuals who are able to provide high levels of circulating antibody and thus possess a high natural resistance to certain endemic diseases.

In order to further our understanding of the causes of difference between the mean $\gamma$ globulin levels of ethnic groups it is important to ascertain whether this difference is present at birth, and if not, to determine the age at which it first becomes manifest.

Received for publication 15 December 1960.
Symul (1950), using a chemical method of analysis, found all fractions in African cord blood close to the

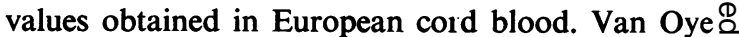
and Charles (1951), also using a chemical method, $\overrightarrow{\vec{O}}$ found all fractions, but especially the $\beta$ and $\gamma \exists$ globulin, lower in the cord blood of African babies as compared with that of African adults. Bersohn, Wayburne, Hirsch, and Sussman (1954), again employing a chemical method, found no significant? differences between the albumin and total globulin levels of European and African infants at birth, but the $\gamma$ globulin level of the African was significantly을 higher than that of the Europeans. Stanier and Thompson (1954) measured the serum proteins of $\frac{\text { ? }}{3}$ African umbilical cord blood, maternal blood, and $\frac{D}{O}$ the blood of young African infants in Uganda by microelectrophoresis (Antweiler) and reported that $N^{N}$ the main differences as compared with corresponding data on white persons were significantly lower mean levels of albumin and $\beta$ globulin: the mean $\alpha$ and $\gamma^{\omega}$ globulin levels at birth were found to be the same as for white persons. Their results for the African infants were compared with values obtained by Longsworth, Curtis, and Pembroke (1945) for American babies. Electrophoretic data from dif- $\frac{7}{0}$ ferent laboratories are unfortunately notorious for $\stackrel{0}{\bar{D}}$

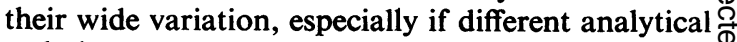
techniques are employed, and the conclusions of $\stackrel{\mathbb{Q}}{\varrho}$ Stanier and Thompson (1954) must be viewed 
against this background. Close (1955) found that the $\gamma$ globulin concentration was lower in the newborn African child than in the European child and related this to poor nutrition. Thompson (1956) investigated the serum proteins in Uganda Africans under 18 months of age and concluded that the serum protein pattern in the first month of life is similar to that found in Europe and America and that the characteristic adult pattern becomes evident towards the end of the first year.

The reports available at present about the serum proteins of newborn Africans as compared with newborn Europeans thus provide very contradictory information and there is therefore need for further study, in particular for study of the newborn of both races by the same observers using identical methods. This has been done in the present investigation, the results of which are presented here.

\section{MATERIALS AND METHODS}

The human subjects studied are: (1) Seventy-five healthy adult women in Ibadan, being part of the group of 350 adult Nigerians previously reported; (2) 68 Nigerian

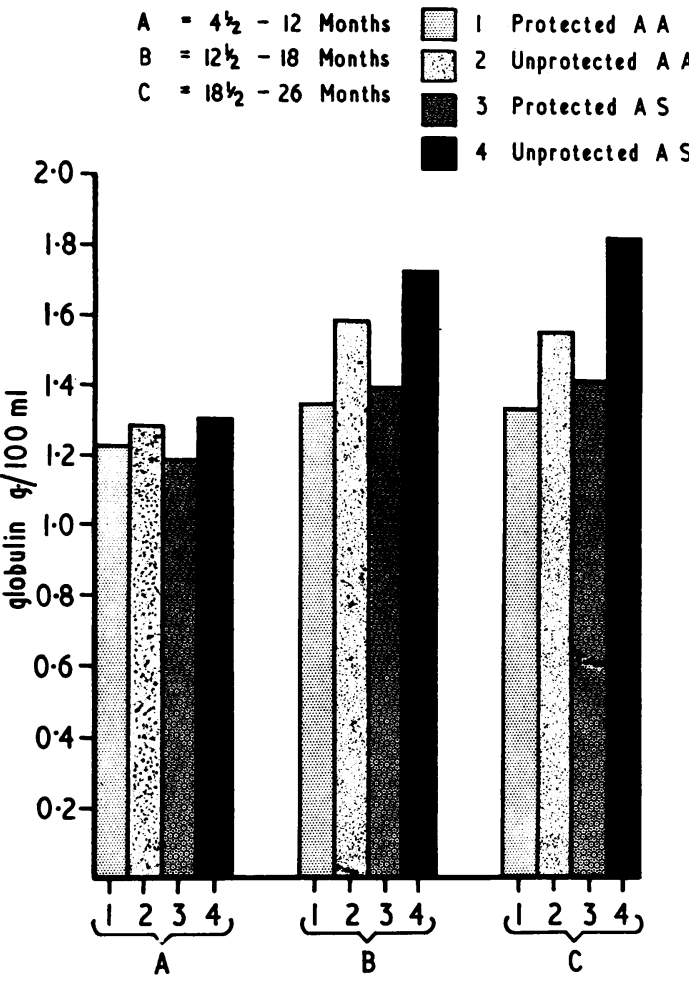

FIG. 1. The effect of malaria prophylaxis on the serum $\gamma$ globulin concentration in children (drawn from the figures in Edozien et al.). women in the second and third trimesters of normal pregnancy; (3) 71 umbilical cord bloods of Nigerian babies and the bloods of 67 of their mothers collected within 12 hours of delivery (some of the children were followed at monthly intervals up till 6 months); (4) 20 umbilical cord bloods of European babies and the bloods of 12 of their mothers also collected within 12 hours of delivery; (5) 113 children aged $4 \frac{1}{2}$ to 26 months at Imesi, a village approximately 100 miles north-east of Ibadan. These were part of the group of 211 children previously reported (Edozien et al., 1960) but as 98 of these children were protected from malaria by monthly doses of pyrimethamine (Daraprim) they have been excluded from the present investigation. (6) One hundred and fifty-six children aged $2 \frac{1}{2}$ to $6 \frac{1}{2}$ years at Ilesha, a town very close to Imesi.

Blood was collected by femoral vein puncture from the children and from an antecubital vein in the adults.

The handling of the specimens and the method for estimating total proteins and the protein fractions were those described previously (Edozien et al., 1960). Immuno-electrophoresis was performed according to the procedure of Grabar (1959). Difco bactoagar was used without further purification. The unstained slides were photographed immersed in tap water: they were then stained with $1 \%$ bromophenol blue for two minutes and washed for 10 minutes in $10 \%$ acetic acid followed by tap water for 18 hours.

\section{RESULTS}

The mean values, together with standard deviations for the total serum proteins and the protein fractions in healthy adult women in Ibadan, and in normal pregnancy are given in Table I. Compared with adult Europeans, the non-pregnant Nigerian women have lower albumin and higher $\gamma$ globulin concentrations but this is the usual pattern in symptomfree Nigerians. In pregnancy there is a progressive fall in the concentration of total protein and of albumin and a rise in the concentration of $\alpha_{1}, \alpha_{2}$, and $\beta$ globulins. These changes are most marked at term. There is also a drop in the $\gamma$ globulin concentration towards the end of pregnancy. These changes are similar to those which take place in pregnant European and American women (Poidevin, 1954; Mack, 1955).

Table II shows the mean values for the total proteins and the protein fractions in the serum of umbilical cord blood of African and European babies and in the blood of their mothers taken on the day of delivery. The individual values are represented graphically in Figs. 2 to 7 . The statistical significance of the results is recorded in Table III. The results for European mothers and for the cord blood of European babies agree very closely with the results of others (Longsworth et al., 1945; Beach, Coryell, Moyer, Robinson, Schoeb, Wiseman, Macy, and Mack, 1952; Moore, Du Pan, and 
TABLE I

SERUM PROTEINS IN NON-PREGNANT WOMEN AND IN NORMAL PREGNANCY

\begin{tabular}{|c|c|c|c|c|c|c|c|c|c|c|c|c|c|c|}
\hline & \multicolumn{2}{|c|}{$\begin{array}{l}\text { Non-pregnant } \\
\text { Women }(75)\end{array}$} & \multicolumn{4}{|c|}{ Second Trimester (24) } & \multicolumn{4}{|c|}{ Third Trimester (39) } & \multicolumn{4}{|c|}{ Term $^{2}(67)$} \\
\hline & & & \multirow{2}{*}{ Mean } & \multirow{2}{*}{ S.D. } & \multirow[t]{2}{*}{$t^{1}$} & \multirow{2}{*}{$p^{1}$} & \multirow[t]{2}{*}{ Mean } & \multirow{2}{*}{ S.D. } & \multirow[t]{2}{*}{$t^{1}$} & \multirow{2}{*}{$p^{1}$} & \multirow{2}{*}{ Mean } & \multirow{2}{*}{ S.D. } & \multirow[t]{2}{*}{$t^{1}$} & \multirow[t]{2}{*}{$p^{1}$} \\
\hline & Mean & $S . D$. & & & & & & & & & & & & \\
\hline Total proteins & $7 \cdot 02$ & 0.41 & $6 \cdot 75$ & 0.59 & $2 \cdot 5$ & $0.01<\mathrm{p}<0.02$ & $6 \cdot 80$ & 0.73 & $2 \cdot 3$ & $0.01<\mathrm{p}<0.02$ & 6.35 & 0.57 & $7 \cdot 5$ & $\mathrm{p}<0.01$ \\
\hline Albumin & 3.50 & 0.31 & 2.66 & 0.46 & $10 \cdot 1$ & $\mathrm{p}<0.01$ & $2 \cdot 61$ & 0.35 & 13.9 & $\mathrm{p}<0.01$ & $2 \cdot 12$ & 0.34 & $25 \cdot 3$ & $\mathrm{p}<0.01$ \\
\hline$\alpha_{1}$ globulin & 0.25 & 0.09 & 0.35 & 0.11 & $4 \cdot 6$ & $\mathrm{p}<0.01$ & 0.38 & 0.12 & $6 \cdot 5$ & $\mathrm{p}<0.01$ & 0.48 & 0.11 & $13 \cdot 5$ & $\mathrm{p}<0.01$ \\
\hline$\alpha_{2}$ globulin & 0.51 & $0 \cdot 13$ & 0.78 & $0 \cdot 18$ & $8 \cdot 0$ & $\mathrm{p}<0.01$ & 0.82 & $0 \cdot 15$ & $12 \cdot 7$ & $\mathrm{p}<0.01$ & 0.89 & 0.16 & $15 \cdot 3$ & $\mathrm{p}<0.01$ \\
\hline$\beta$ globulin & 0.73 & $0 \cdot 18$ & 0.93 & $0 \cdot 15$ & $5 \cdot 0$ & $\mathrm{p}<0.01$ & 0.98 & $0 \cdot 16$ & $7 \cdot 7$ & $\mathrm{p}<0.01$ & 1.07 & $0 \cdot 17$ & $11 \cdot 7$ & $\mathrm{p}<0.01$ \\
\hline$\gamma$ globulin & 2.03 & 0.34 & 2.03 & 0.44 & 0.0 & - & 2.02 & 0.49 & $0 \cdot 1$ & $0.8<p<0.9$ & 1.79 & 0.45 & $3 \cdot 6$ & $\mathrm{p}<0.01$ \\
\hline
\end{tabular}

${ }^{1}$ Test of the significance of difference from value for non-pregnant women.

${ }^{2}$ Blood collected within 12 hours after delivery.

TABLE II

SERUM PROTEINS OF MATERNAL AND CORD BLOOD

\begin{tabular}{|c|c|c|c|c|c|c|c|c|}
\hline & \multicolumn{2}{|c|}{ African Mothers (67) } & \multicolumn{2}{|c|}{ African Infants (71) } & \multicolumn{2}{|c|}{ European Mothers (12) } & \multicolumn{2}{|c|}{ European Infants (19 } \\
\hline & Mean & S.D. & Mean & S.D. & Mean & S.D. & Mean & $S . D$. \\
\hline Total proteins & $6 \cdot 35$ & 0.57 & $6 \cdot 10$ & 0.59 & $5 \cdot 26$ & 0.44 & $5 \cdot 53$ & 0.42 \\
\hline Albumin & $2 \cdot 12$ & 0.34 & $2 \cdot 82$ & 0.35 & $2 \cdot 02$ & 0.29 & $2 \cdot 79$ & $0 \cdot 50$ \\
\hline$\alpha_{1}$ globulin & 0.48 & $0 \cdot 11$ & 0.29 & $0 \cdot 17$ & 0.44 & $0 \cdot 13$ & 0.30 & $0 \cdot 11$ \\
\hline$\alpha_{2}$ globulin & 0.89 & $0 \cdot 16$ & 0.58 & $0 \cdot 16$ & 0.84 & $0 \cdot 15$ & 0.54 & 0.13 \\
\hline$\beta$ globulin & 1.07 & $0 \cdot 17$ & 0.76 & 0.23 & 1.06 & $0 \cdot 14$ & 0.69 & 0.25 \\
\hline
\end{tabular}

TABLE III

STATISTICAL SIGNIFICANCE OF RESULTS SHOWN IN TABLE II

\begin{tabular}{|c|c|c|c|c|c|}
\hline & & $\begin{array}{l}\text { African Mothers } \\
\text { Compared with } \\
\text { European Mothers }\end{array}$ & $\begin{array}{l}\text { African Infants } \\
\text { Compared with } \\
\text { European Infants }\end{array}$ & $\begin{array}{l}\text { African Infants } \\
\text { Compared with } \\
\text { African Mothers }\end{array}$ & $\begin{array}{l}\text { European Infants } \\
\text { Compared with } \\
\text { European Mothers }\end{array}$ \\
\hline \multirow[t]{2}{*}{ Total proteins } & $\mathbf{t}$ & $5 \cdot 82$ & 2.63 & $2 \cdot 83$ & $2 \cdot 28$ \\
\hline & $\mathrm{p}$ & $\mathrm{p}<0.01$ & $\mathrm{p}<0.01$ & $\mathrm{p}<0.01$ & $0.02<p<0.05$ \\
\hline \multirow[t]{2}{*}{ Albumin } & & 0.96 & 0.30 & 12.06 & 4.84 \\
\hline & $\mathrm{p}$ & $0.3<\mathrm{p}<0.4$ & $0.7<p<0.8$ & $p<0.01$ & $\mathrm{p}<0.01$ \\
\hline \multirow[t]{2}{*}{$\alpha_{1}$ globulin } & $\mathrm{t}$ & 0.55 & 0.36 & 6.97 & $3 \cdot 17$ \\
\hline & $\mathrm{p}$ & $0.5<\mathrm{p}<0.6$ & $0.7<\mathrm{p}<0.8$ & $p<0.01$ & $\mathrm{p}<0.01$ \\
\hline \multirow[t]{2}{*}{$\alpha_{2}$ globulin } & $\mathrm{t}$ & 1.02 & 0.98 & 11.46 & $\begin{array}{r}5.86 \\
\end{array}$ \\
\hline & $\mathrm{p}$ & $0.3<\mathrm{p}<0.4$ & $0.3<\mathrm{p}<0.4$ & $\mathrm{p}<0.01$ & $p<0.01$ \\
\hline \multirow[t]{2}{*}{$\beta$ globulin } & $\mathrm{t}$ & 0.19 & 1.15 & 9.01 & 4.67 \\
\hline & p & $0.8<p<0.9$ & $0.2<p<0.3$ & $p<0.01$ & $\mathrm{p}<0.01$ \\
\hline \multirow[t]{2}{*}{$\gamma$ globulin } & $\mathrm{t}$ & 6.68 & $6 \cdot 10$ & $2 \cdot 22$ & 3.42 \\
\hline & $\mathrm{p}$ & $\mathrm{p}<0.001$ & $\mathrm{p}<0.01$ & $0.02<p<0.05$ & $p<0.01$ \\
\hline
\end{tabular}

Buxton, 1949; Norton, Kunz, and Pratt, 1953; Sohar, Bossak, Wang, and Adlersberg, 1956; Sternberg, Dagenais-Perusse, and Dreyfuss, 1956). No significant differences were found in the mean values for albumin, $\alpha_{1}, \alpha_{2}$, and $\beta$ globulins of African mothers as compared with European mothers or of African children at birth as compared with European children at birth. No correlation exists between the concentrations of these fractions in the umbilical cord blood and in the blood of the mothers. In both groups albumin concentration in cord blood is greater than in mother's blood while the concentrations of $\alpha_{1}, \alpha_{2}$, and $\beta$ globulins are significantly lower in cord blood than in mother's blood. As $N$ expected the $\gamma$ globulin concentration in the blood of African mothers is significantly higher than the concentration of the same fraction in the blood of ${ }^{\mathrm{w}}$ European mothers. The mean concentration of $\gamma$ globulin in the umbilical cord blood of Europeane babies is significantly higher than the concentration in the blood of their mothers: good correlation exists ?between the concentration of the $\gamma$ fraction in the $\frac{T}{0}$ cord blood and the concentration in the mother's $\frac{\vec{D}}{2}$ blood (Fig. 6). The relation of the $\gamma$ globulin con- $\frac{\rho}{\stackrel{1}{Q}}$ centration in the cord blood of African babies to $\stackrel{\Phi}{\mathscr{D}}$ the level in their mothers is complex. Examination? 


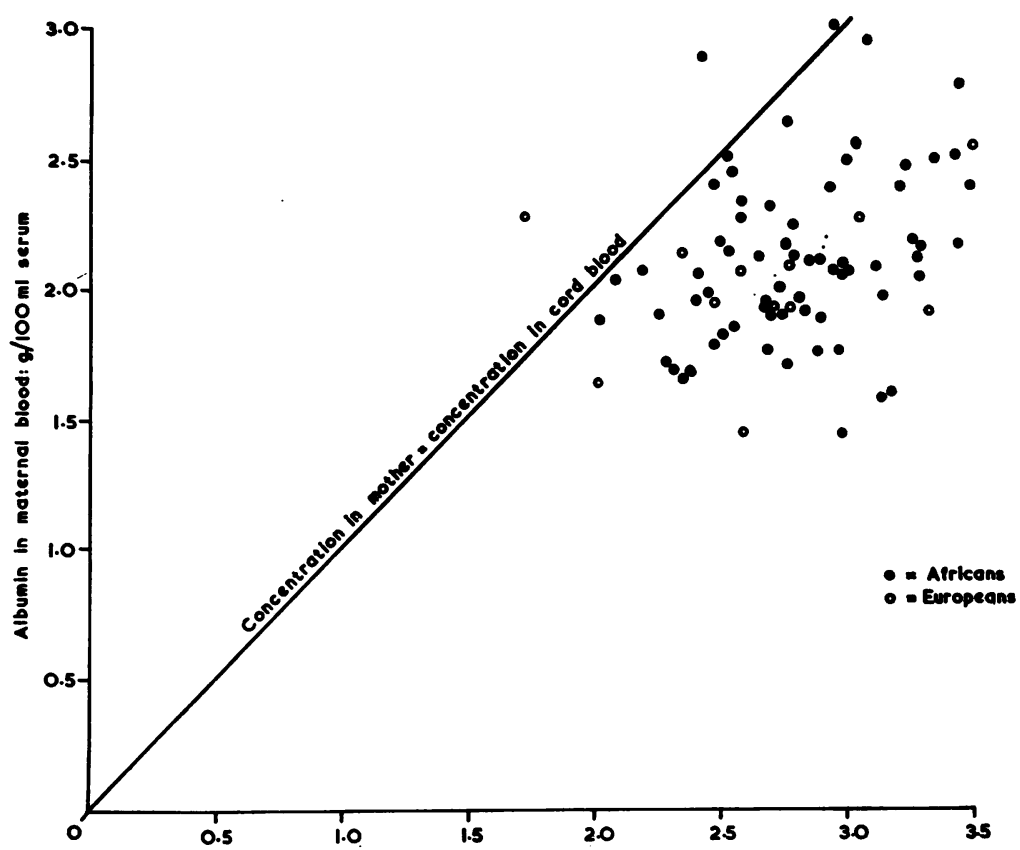

FIG. 2

Albumin in cord blood: $9 / 100 \mathrm{ml}$ serum

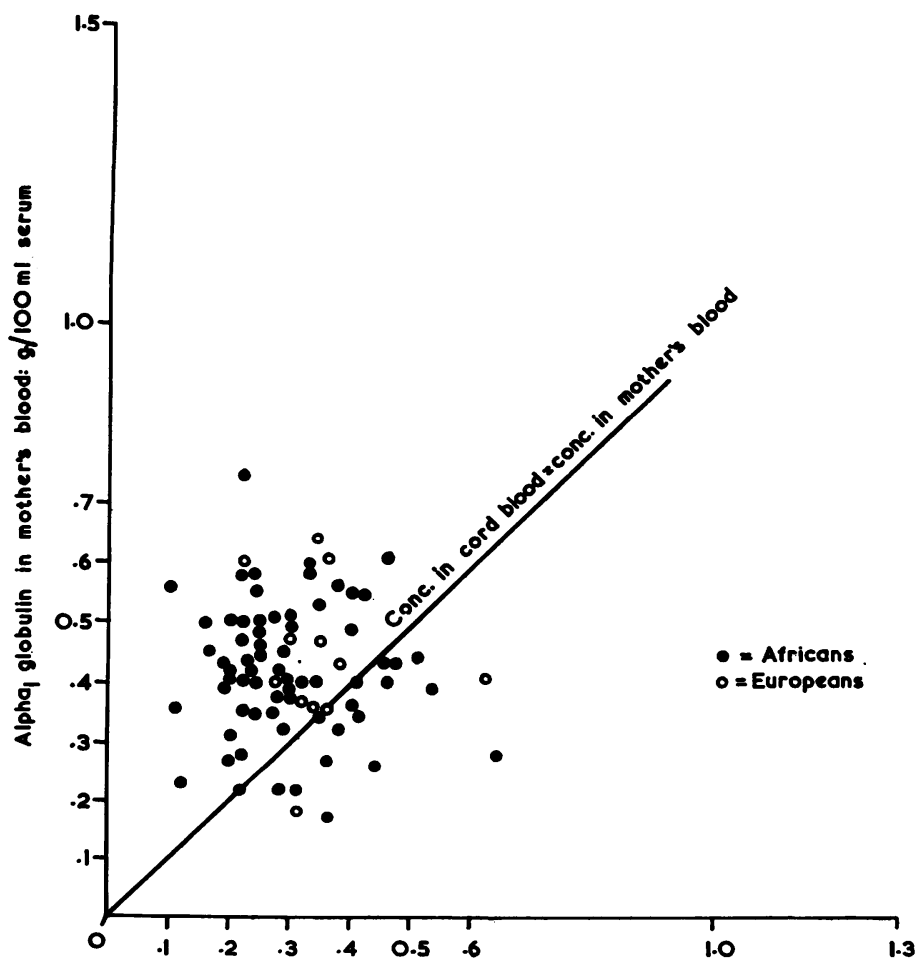

FIG. 2. Relation of albumin concentration in maternal and cord blood sera.

FIG. 3. Relation of $a_{1}$ globulin concentration in maternal and cord blood sera.

FIG. 3 Alpha, globulin in cord blood: $9 / 100 \mathrm{ml}$ serum 


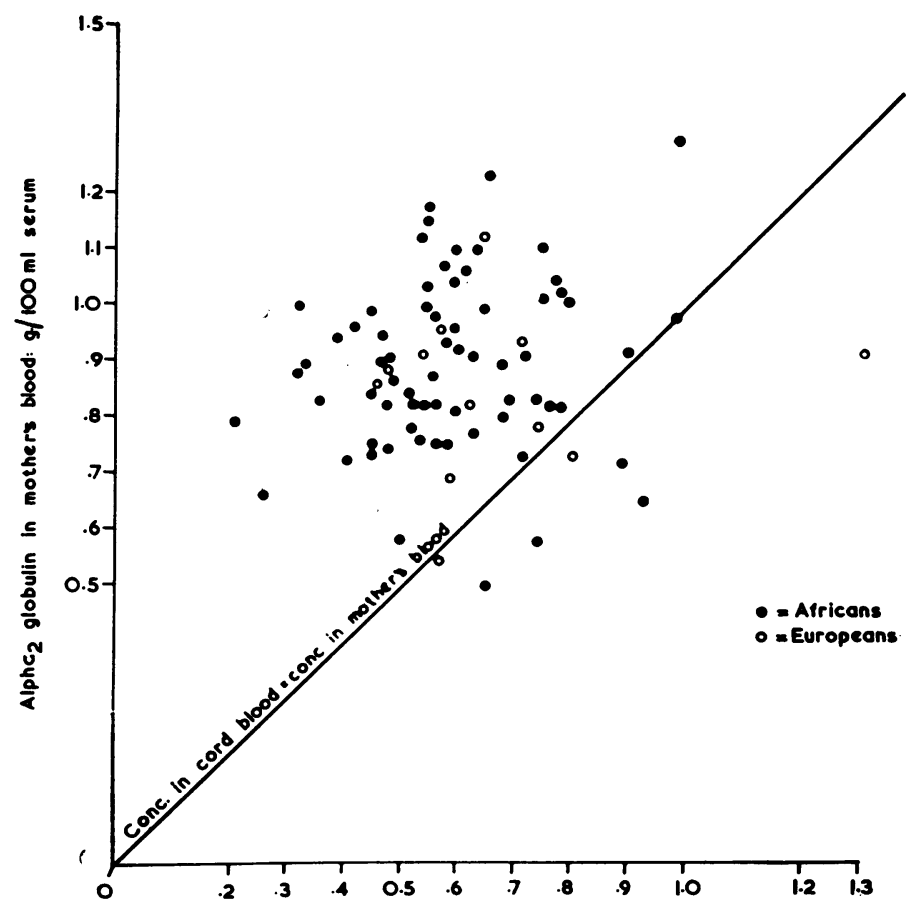

FIG. 4. Relation of $a_{2}$ globulin concentration in maternal and cord blood sera.

FIG. 4

Alpha $_{2}$ globulin in cord blood: $9 / 100 \mathrm{ml}$ serum

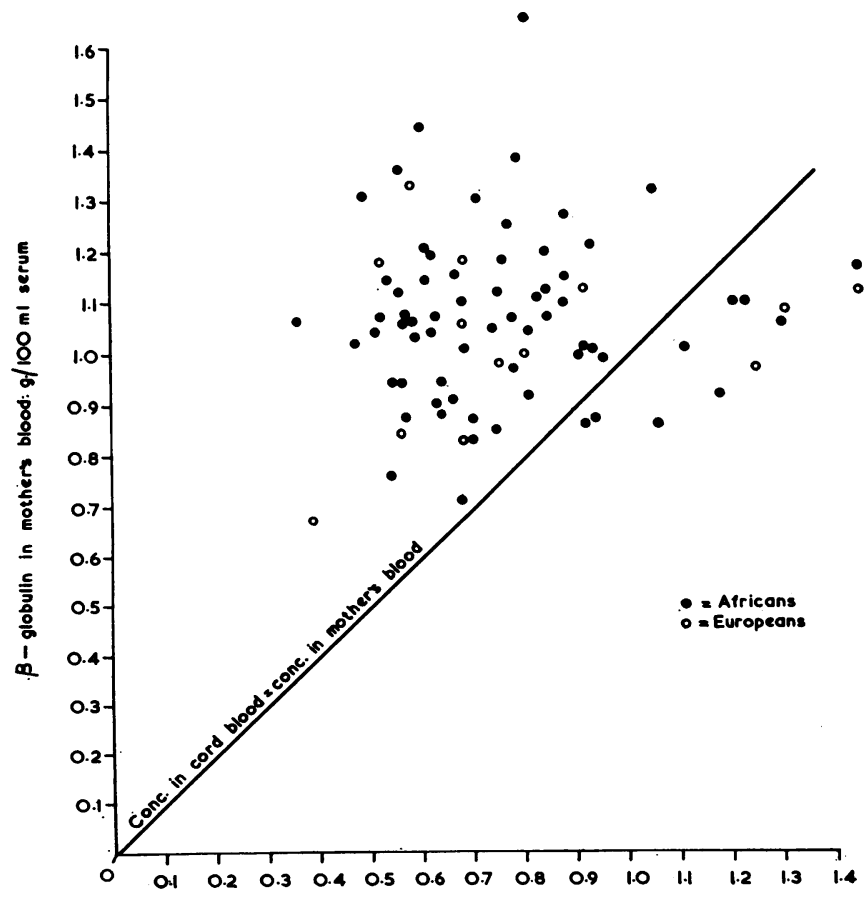

FIG. 5. Relation of $\beta$ globulin concentration in maternal and cord blood sera.

FIG. 5

$\beta$-globulin in cord blood: $9 / 100 \mathrm{ml}$ serum 


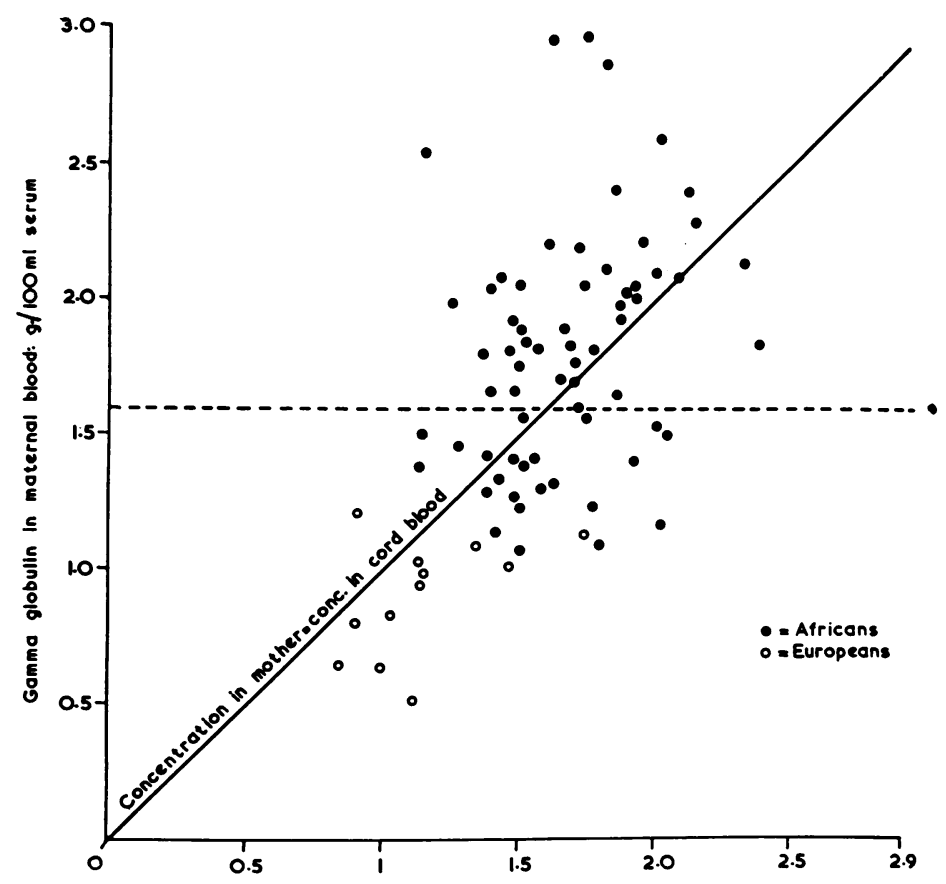

FIG. 6. Relation of $\gamma$ globulin concentration in maternal and cord blood sera.

FIG. 7. Gamma globulin concentrations in maternal and cord blood sera of Africans and Europeans.

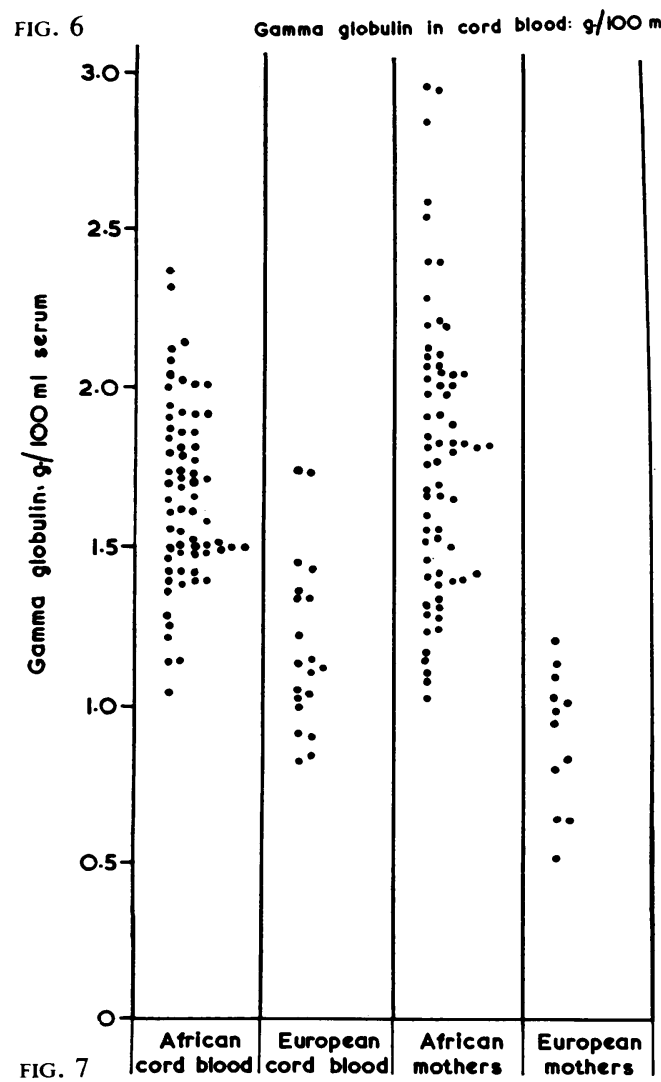

of Fig. 6 shows that African mothers with $\gamma$ globulin concentrations below $1.6 \mathrm{~g} . / 100 \mathrm{ml}$. generally have babies whose $\gamma$ globulin level is higher than that of their mother, while women with $\gamma$ globulin level over $1.6 \mathrm{~g} . / 100 \mathrm{ml}$. have babies whose $\gamma$ globulin concentration is below that of their mother. The mean $\gamma$ globulin level in African umbilical cord blood is very significantly higher than the mean level in European umbilical cord blood so that the difference between the two races in this respect exists even at birth.

Fig. 8 presents two typical immuno-electrophoretic patterns in cord blood and in mother's blood. No differences have been observed between the pattern in Europeans and Africans. In most cases the cord blood shows fewer antigenic components in the $\alpha_{2}, \beta$, and $\gamma$ globulin zones than in the mother's blood.

In Table IV and in Fig. 9 are shown the mean values for total serum proteins and the protein fractions in healthy adults in cord blood and in children at different ages up to 6 years. At birth the total proteins are slightly lower than adult mean value, but attains this value at 6 months and stays there. The albumin level is slightly lower than adult mean value at birth but also rapidly attains that value (at 1 month). The slight drop in total serum proteins and albumin at about 2 years is probably related to the decrease in protein intake 


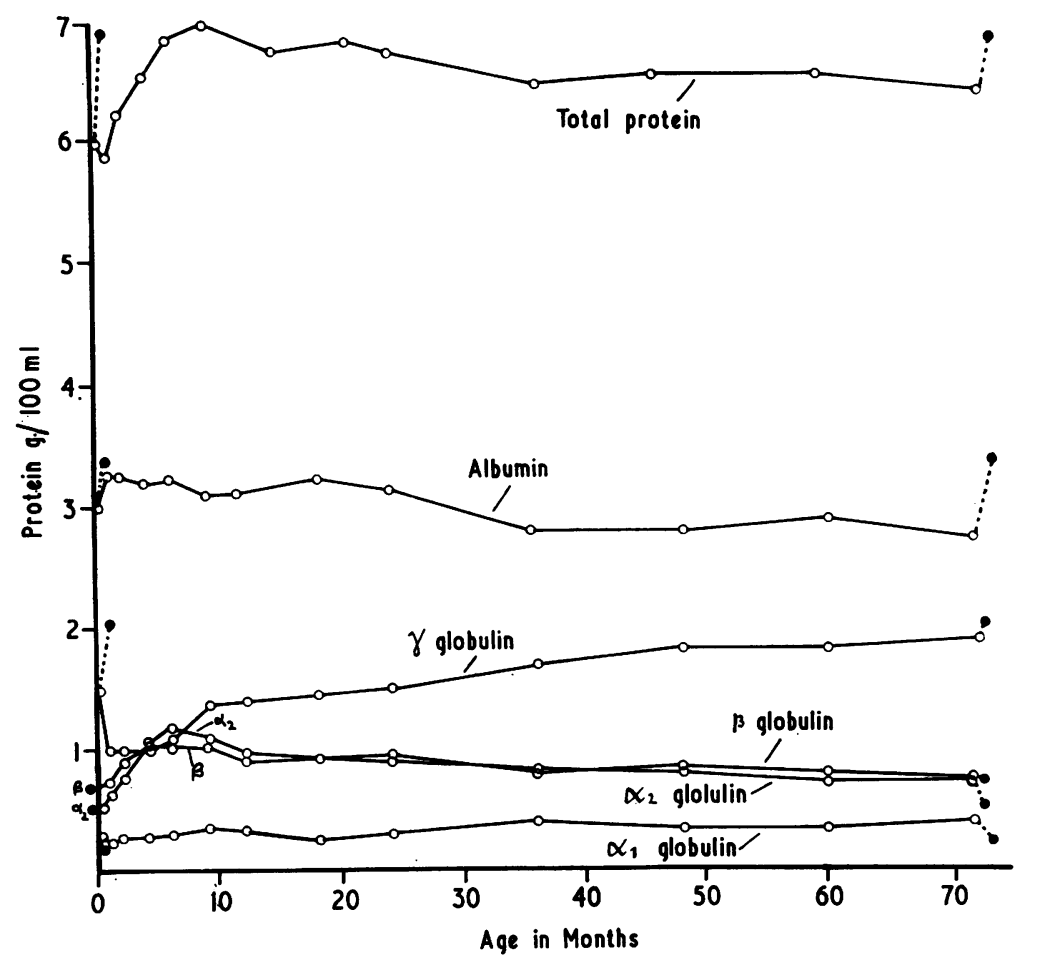

FIG. 8. Changes in serum proteins with age (solid dots represent adult values).

from breast milk following weaning. Alpha 1 globulin is normal at birth and does not show any notable changes throughout infancy and childhood. Alpha 2 globulin is normal at birth, rises to a maximum at about 6 months, and then falls gradually but at 6 years it has not returned to normal adult level. Beta globulin, also normal at birth, rises to a maximum at approximately 6 months and gradually returns to normal level which it reaches by the age of 3 years. At birth $\gamma$ globulin concentration is about $75 \%$ of adult mean concentration: it falls rapidly to reach a minimum value by the end of the first month, remains at this low level for four to five months and begins to increase by the sixth month. A large increase occurs at 6 to 9 months of age followed by a more gradual rise and by 6 years it has not attained adult level. The rapid increase at 6 to 9 months of age is probably unrelated to malaria since the effect of malaria becomes evident after the age of 12 months (Edozien et al., 1960; McGregor and

TABLE IV

SERUM PROTEINS AT DIFFERENT AGES UP TO 6 YEARS

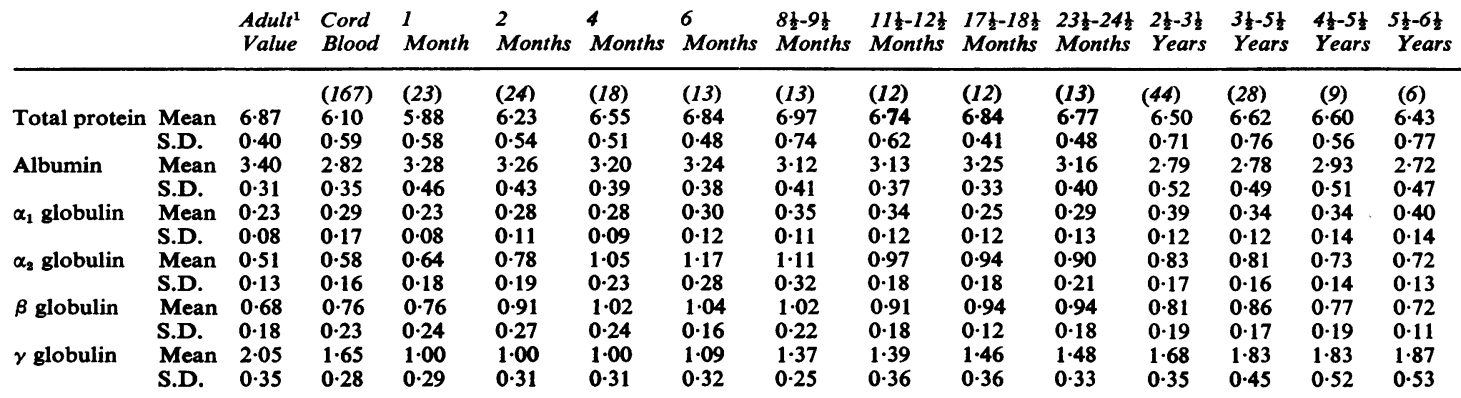

'Values taken from Edozien et al. (1960). 


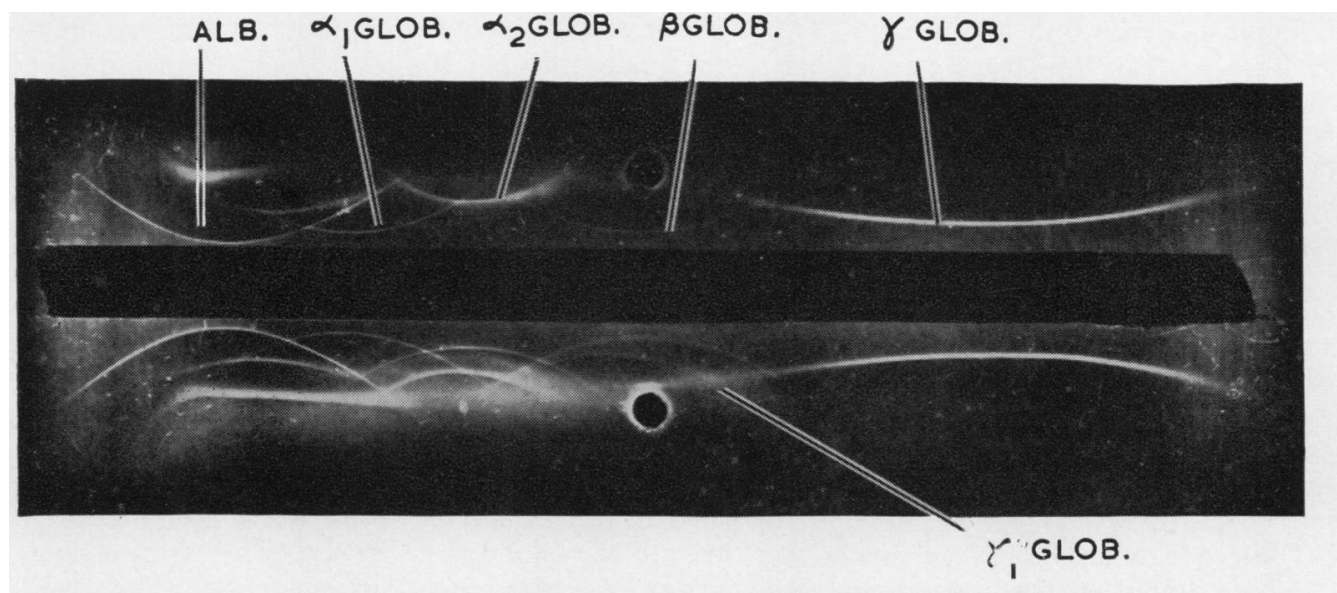

CORD

MOTHER

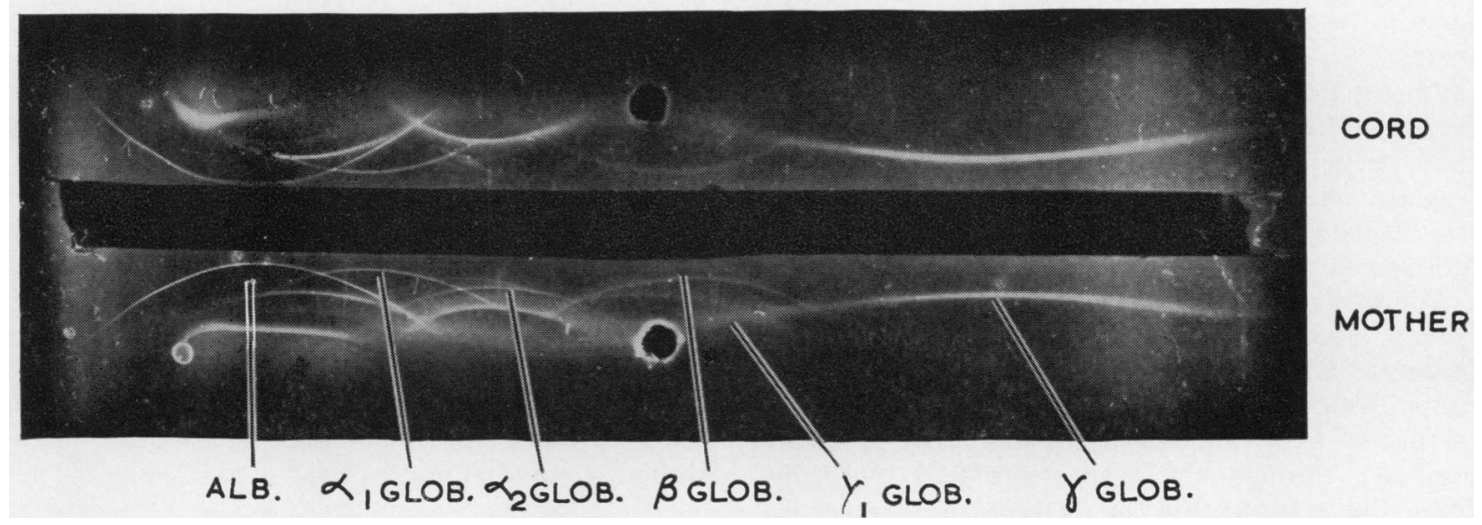

FIG. 9. Immunoelectrophoresis of maternal and cord blood sera (horse-immune serum from Pasteur institute, Paris, was used). Note that maternal sera have at least two components each in the $a_{2}$ and $\beta$ globulin envelopes while the cord blood sera show only one component each distinctly. Also the $\gamma_{1}$ globulin zone is not well developed in cord blood sera.

Gilles, 1959). In general these changes follow the pattern described in Europeans (Longsworth et al., 1945; Moore et al., 1949; Sternberg et al., 1956; Homolka and Mydlil, 1955; Oberman, Gregory, Burke, Ross, and Rice, 1956; Josephson and Gyllensward, 1957) except that in Africans the changes in $\gamma$ globulin occur at a higher level.

\section{DISCUSSION}

These data show very clearly that the difference in serum $\gamma$ globulin concentration between Africans and Europeans is present at birth. The question which arises from this observation is whether the concentration of $\gamma$ globulin in the serum of the newborn is a genetically determined value or whether it is dependent on the level in the mother.

Close correlation has been demonstrated between the level of $\gamma$ globulin in cord blood and in maternal blood and this indicates that conditions in the mother probably control the $\gamma$ globulin content of the serum in the newborn child. The rapid decline in serum $\gamma$ globulin concentration during the neonatal period to reach a steady low level by the end of the first month further suggests that before parturition there may be a transfer of $\gamma$ globulin from maternal to foetal circulation since most of the $\gamma$ globulin so transferred before birth would be expected to disappear from the infant's blood within 28 days, assuming that the half-life of human serum $\gamma$ globulin is 10 to 20 days (London, 1950; Dixon, Maurer, and Deichmiller, 1953; Dixon, Talmage, Maurer and Deichmiller, 1952). Moreover, there is evidence that in man antibodies, which are $\gamma$ globulins (Tiselius and Kabat, 1939; Williams, Petermann, Colovos, Goodloe, Oncley, and Armstrong, 1944; Enders, 1944; Haurowitz, 1947; Boyd, 1954; Isliker, 1957), can be transferred in utero from 
mother to foetus (Wiener and Silverman, 1940; Kuttner and Ratner, 1923; Ten Broeck and Bauer, 1923; Pommerenke, 1936; Ratner, Jackson, and Gruehl, 1927; Sherman, Hampton, and Cooke, 1940; Bell and Eriksson, 1931; Neill, Gaspari, Richardson, and Sugg, 1932; Wright and Clerk, 1944). Indeed several observers (Moore et al., 1949; Good and Zak, 1956; Franklin and Kunkel, 1958) believe that the newborn infant is unable to synthesize $\gamma$ globulin and that therefore all the globulin present in the foetus at birth is derived from the mother by transfer through the placenta. This conclusion is based upon the following evidence: (1) After birth the serum $\gamma$ globulin level gradually falls until the onset of antibody synthesis at the age of 5 to 6 months. (2) Only specific antibodies present in the mother have been found in cord blood and the amount in cord blood is usually below the level in maternal blood. (3) The higher molecular weight (19S) fraction of the globulin is absent from cord blood. (4) The observation of Good and Zak (1956) that the baby of an agammaglobulinaemic mother was also agammaglobulinaemic at birth and during the neonatal period and did not begin to form $\gamma$ globulin until the end of the second month of life.

However, uterine transmission is probably not a simple exchange of serum proteins across the placenta. Cohen (1950) has observed that in the rabbit, which has a placenta very similar in structure to that of man, the passing of homologous serum antibody through the placenta differs markedly from the transmission of heterologous serum $\gamma$ globulin. The concentration of albumin is significantly higher in cord blood than in mother's blood while the concentrations of $\alpha_{1}, \alpha_{2}$, and $\beta$ globulins are significantly lower in cord blood. The immunoelectrophoretic data also demonstrate that some protein components with the electrophoretic mobility of $\alpha_{2}, \beta_{1}$, and $\gamma_{1}$ globulins may be absent from cord blood although present in maternal blood. While it is possible to explain most of the differences in protein composition between maternal and foetal sera in the human species by haemoconcentration of foetal blood, coupled with the presence of large molecules within the $\alpha_{2}, \beta_{1}$, and $\gamma_{1}$ globulin envelopes, nevertheless, the observation that the transfer of $\gamma$ globulin from mother to foetus appears to be inhibited when the concentration of $\gamma$ globulin in the maternal blood rises above a certain critical value, does suggest that in man the transfer of $\gamma$ globulin from mother to foetus is a more complex process than simple diffusion across the placenta.

The concentration of $\gamma$ globulin in the blood of the newborn is the result of the rapidly declining component derived from the mother prior to parturition and the rising contribution by the baby under the influence of its genetic constitution and/or in response to environmental stimuli. Much further investigation is needed before it is possible to assess clearly the relative importance of each of these factors.

During infancy and childhood the changes in the serum $\gamma$ globulin concentration in Africans follow the pattern which has been described in Europeans but at a higher level. Here also the questions may be asked whether the African has inherited a greater innate capacity to form $\gamma$ globulin or whether his high $\gamma$ globulin level is an expression of a more highly infected environment or whether his normal environment contains infective agents which provoke greater $\gamma$ globulin response? Attemps have been made to answer these questions by a study of the concentration of $\gamma$ globulin in the serum of Africans living under European conditions of life (Schofield, 1957; Van Oye and Charles, 1957). This approach is not likely to produce valid and conclusive evidence, because the capacity of individuals to respond to any situation should normally be assessed after applying the correct stimulus; hence, in order to answer these questions, it would be more appropriate to study the $\gamma$ globulin concentration in Europeans and in other races under conditions comparable to those in which the majority of Africans grow up. It is not sufficient only to investigate Africans who have never been exposed to the necessary environmental stimuli. There are a number of natural situations in the world at present where other races can be investigated under African conditions of life and valuable information may accrue from such a study. Antibodies probably constitute the principal basis of immunity, and because antibodies are $\gamma$ globulins and there is little doubt that individuals and ethnic groups may vary in inborn resistance to endemic infections, further study of this problem may enhance our understanding of race and group immunity.

My thanks are due to Drs. J. B. Lawson, W. T. Fullerton, R. Hendrickse, all of University College, Ibadan, and Dr. D. C. Morley, Wesley Guild Hospital, Ilesha, for their help and cooperation over the collection of specimens, and to Mrs. E. C. Odim, B.S., and Mr. D. I. Tabansi, A.M.I.L.T., for technical assistance.

\section{REFERENCES}

Bakker, A. W. I., Bliek, A., and Luyken, R. (1957). Docum. Med. geogr. trop. (Amst.), 9, 1.

Beach, E. F., Coryell, M. N., Moyer, E. Z., Robinson, A. R., Schoeb, E. J., Wiseman, M. E., Macy, I. G., and Mack, H. C. (1952). Proc. Soc. exp. Biol. (N.Y.), 80, 235.

Bell, S. D., and Eriksson, Z. (1931). J. Immunol. 20, 447.

Bersohn, I., Wayburne, S., Hirsch, H., and Sussman, C. D. (1954). S. Afr. J. clin. Sci., 5, 35.

Boyd, W. C. (1954). In The Proteins, Vol. 2, Part B, p. 755. Ed. H. Neurath and K. Bailey. Academic Press, New York.

Close, J. (1955). Ann. Soc. belge Méd. trop., 35, 129. 
Cohen, S. G. (1950). J. infect. Dis., 87, 291.

Comens, P. (1957). Amer. J. Sci., 233, 275.

Curnow, D. H. (1957). Med. J. Aust., 2, 608.

Dixon, F. J., Maurer, P. H., and Deichmiller, M. P. (1953). Proc. Soc. exp. Biol. (N.Y.), 83, 287.

—, Talmage, D. W., Maurer, P. H., and Deichmiller, M. (1952). J. exp. Med., 96, 313.

Edozien, J. C. (1957). J. clin. Path., 10, 276.

- (1958). W. Afr. med. J., 7, 121.

- , Boyo, A. E., and Morley, D. C. (1960). J. clin. Path. 13, 118.

Enders, J. F. (1944). J. clin. Invest., 23, 510.

Franklin, E. C., and Kunkel, H. G. (1958). J. Lab. clin. Med., 52, 724.

Good, R. A., and Zak, S. J. (1956). Pediatrics, 18, 109.

Grabar, P. (1959). Meth. biochem. Anal., 7, 1.

Haurowitz, F. (1947). Lancet, 1, 149.

Holmes, E. G., Stanier, N. W., and Thompson, M. D. (1955). Trans. roy. Soc. trop. Med. Hyg., 49, 376.

Homolka, J., and Mydlil, V. (1955). Ann. paediat (Basel), 185, 129.

Isliker, H. C. (1957). Advanc. Protein Chem., 12, 387.

Josephson, B., and Gyllensward, C. (1957). Scand. J. clin. Lab. Invest., 9, 29.

Keltz, H., and Comstock, G. W. (1959). New Engl. J. Med., 260, 1268.

Kuttner, A., and Ratner, B. (1923). Amer. J. Dis. Child., 25, 413.

London, I. M. (1950). In Symposia on Nutrition: Vol. 2: Plasma Proteins, ed. J. B. Youmans p. 72 (Robert Gould Research Foundation).Thomas, Springfield, Illinois.

Longsworth, L. G., Curtis, R. M., and Pembroke, R. H. (1945). J. clin. Invest., 24, 46.

Mack, H. C. (1955). The Plasma Protein in Pregnancy, 1st ed. Thomas, Springfield, Illinois.

McGregor, I. A., and Gilles, H. M. (1959). Report of the Medical Research Council for 1957-1958, p. 8. H.M. Stationery Office, London. —-, $\frac{1 \text {, Walters, J. H., Davies, A. H., and Pearson, F. A. (1956). }}{\text { Brit. med. J., 2, } 686 .}$
Moore, D. H., Du Pan, R. Martin, and Buxton, C. L. (1949). Amer. J. Obstet. Gynec., 57, 312.

Neill, J. M., Gaspari, E. L., Richardson, L. V., and Sugg, J. Y. (1932). J. Immunol., 22, 117.

Norton, P. M., Kunz, H. and Pratt, E. L. (1953). Pediatrics, 10, 527.

Oberman, J. W., Gregory, K. O., Burke, F. G., Ross, S., and Rice, E. C. (1956). New Engl. J. Med., 255, 743.

Poidevin, L. O. S. (1954). Med. J. Aust, 1, 105.

Pommerenke, W. T. (1936). J. clin. Invest., 15, 485.

Rawnsley, H. M., Yonan, V. L., and Reinhold, J. G. (1956). Science, $123,991$.

Ratner, B., Jackson, H. C., and Gruehl, H. L. (1927). J. Immunol., $14,249$.

Schofield, F. D. (1957). Trans. roy. Soc. trop Med. Hyg., 51, 332.

Sherman, W. B., Hampton, S. F., and Cooke, R. A. (1940). J. exp. Med., 72, 611.

Sohar, E., Bossak, E. T., Wang, Chun-I., and Adlersberg, D. (1956). Science, 123, 461.

Stanier, M. W., and Thompson, M. D. (1954). Arch. Dis. Childh., 29, 110.

Sternberg, J., Dagenais-Perusse, P., and Dreyfuss, M. (1956). Canad. med. Ass. J., 74, 49.

Symul, F. (1950). Ann. Soc. belge med. trop., 30, 295.

Thompson, M. D. (1956). Trans. roy. Soc. trop. Méd. Hyg., 50, 77.

Tiselius, A., and Kabat, E. A. (1939). J. exp. Med., 69, 119.

Ten Broeck, C., and Bauer, J. H. (1923). Proc. Soc. exp. Biol. (N.Y.), 20, 399.

Van Oye, E., and Charles, P. (1951). Ann. Soc. belge Méd. trop., 31, 403.

(1957), Ibid, 37, 955

Vera, J., and Roche, M. (1956). J. Lab. clin. Med., 47, 418.

Wiener, A. S., and Silverman, I. J. (1940). J. exp. Med., 71, 21.

Williams, J. W., Petermann, M. L., Colovos, G. C., Goodloe, M. B., Oncley, J. L., and Armstrong, S. H. Jr. (1944). J. clin. Invest., 23, 433.

Wright, G. P., and Clerk, W. M. (1944). Brit. med. J., 2, 146. 